\title{
Diagnosis of electricity crisis and scope of wind power in Pakistan
}

1 Muhammad Arshad BSC, MSC, ME, PhD

Assistant Professor, Department of Geological Engineering, University of Engineering \& Technology, Lahore, Pakistan (corresponding author: arshadm@tcd.ie) (Orcid:0000-0002-7913-011X)

\author{
2 Brendan C. O'Kelly BE, MEngSC, MAl, PhD, FTCD, \\ CEng, CEnv, MICE \\ Associate Professor, Department of Civil, Structural and \\ Environmental Engineering, Trinity College Dublin, Dublin, Ireland \\ (Orcid:0000-0002-1343-4428)
}
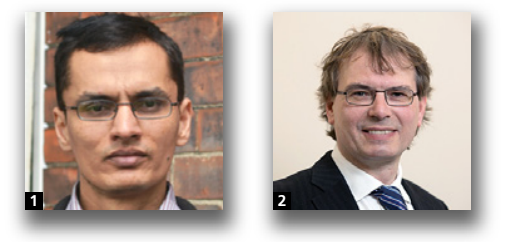

Electricity performs an integral role in the economic development and improvement in the living standard of a nation. Unfortunately, Pakistan is currently experiencing one of its worst periods of power shortages. The purpose of this paper is based on diagnosing the present electricity crisis in Pakistan and to discuss the outlook for the diffusion of wind power in the mix of established electricity generation, which relies too heavily on imported fossil fuels at the cost of precious foreign exchange. The existing electricity transmission and distribution (T\&D) network has miserably failed to meet the country's requirements. Diversification of the present electricity-generation mix, with a significant increase in the contribution from exploitable wind-power potential recommended, along with upgrading and overhaul of existing power plants and the T\&D infrastructure, reductions in non-technical losses and enhancing investment attractiveness (for both thermal and renewable) are some key measures likely to facilitate improved and affordable electricity supply and mitigate the current and forecasted long-term electricity supply-demand gap. Specific recommendations are presented towards overcoming identified challenges and obstacles to the harnessing of the country's abundant renewable energy resources, especially for wind power generation.

\section{Introduction}

Geographically, Pakistan is situated between latitudes $24^{\circ}$ and $37^{\circ}$, longitudes $62^{\circ}$ and $75^{\circ}$, bordering with India to the east, Iran to the west, China to the north and Afghanistan to the northwest (Figure 1). In the south, Pakistan has approximately $1100 \mathrm{~km}$ of coastline with the Arabian Sea and an exclusive economic zone extending up to $370 \mathrm{~km}$ in these hot waters. The total land area of Pakistan is $796950 \mathrm{~km}^{2}$, its population density is 260 inhabitants $/ \mathrm{km}^{2}$ (urban population of $40 \%$ ) and the country has plenty of solar, wind and water resources. Per capita, electricity consumption for 2015-2016 was $457 \mathrm{kWh}$ (Ahmed et al., 2016), almost six times less than the typical average electricity consumption across the developed world (Mirza et al., 2015).

In 2016, the total installed electricity-generation capacity in Pakistan was approximately $25.0 \mathrm{GW}$, against the peak demand of 26.4 GW (NTDC, 2017). For 2013-2017, the actual gap between peak electricity demand and total supply remained in the range 5-8 GW (Mengal et al., 2014; NEPRA, 2017), which represents almost $50 \%$ of the country's dependable electricitygeneration capacity (Shakeel et al., 2016). Furthermore, the present electricity transmission and distribution (T\&D) network in Pakistan is not capable of the efficient and reliable distribution of more than approximately $18 \mathrm{GW}$ to the end users, with the outdated network worsening the supply-demand gap, such that the transmission of anything over this capacity for extended periods increases the likelihood of breakdowns in the distribution network (Ullah, 2013). At present, almost 25\% of the total population in Pakistan has no access to electricity and those that have access are bound to live without electricity on a daily basis for more than $12-14 \mathrm{~h}$ in cities, with the situation often worse at typically $16-18 \mathrm{~h}$ in rural areas (Harijan et al., 2011; Kessides, 2013).

The foremost causes of electricity shortages in Pakistan are closely connected with technical and policy reasons, including unsatisfactory performance of power production plants, the outdated T\&D network and an inefficient energy mix (Latif and Ramzan, 2014; Shaikh et al., 2015). According to Malik (2012) and Valasai et al. (2017), other factors include the underperformance of responsible administrative and regulatory bodies and corruption in the management of the limited capital resources of the power sector. 


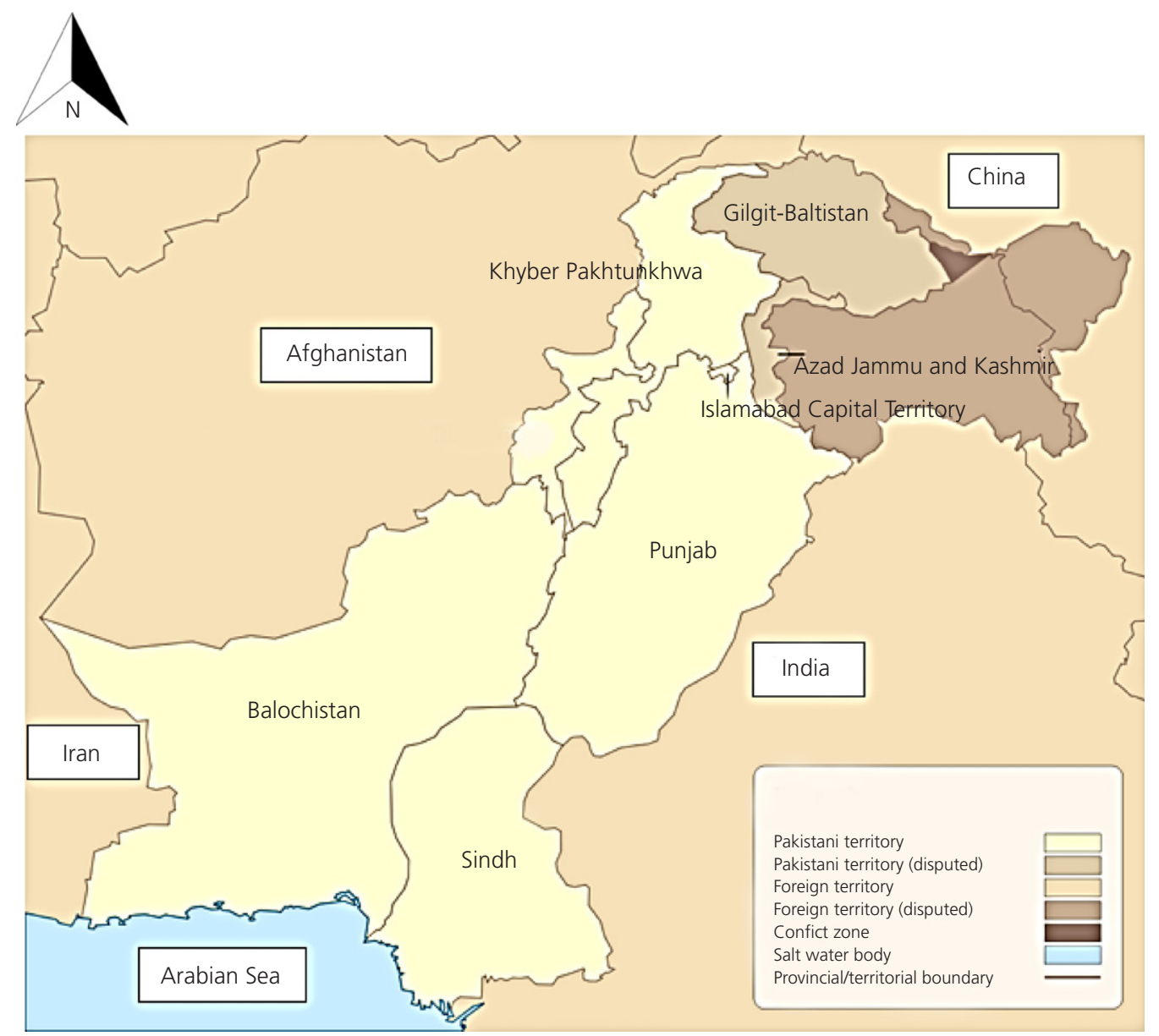

Figure 1. Neighbouring countries and administrative divisions of Pakistan (Mirza et al., 2007)

Numerous studies have demonstrated that Pakistan possesses huge renewable energy (RE) potential, such as from wind (Bhutto et al., 2013; Mengal et al., 2014; Mirza et al., 2010), solar (Bhutto et al., 2012; Jabeen et al., 2014; Khalil and Zaidi, 2014), biomass (Amjid et al., 2011; Bhutto et al., 2011) and geothermal (Abbas et al., 2014) means. Among these, wind energy is relatively more promising for commercial harvesting. For instance, at the time of writing this paper, the share of wind power of the total electricity-generation capacity in Pakistan was only $0.9 \mathrm{GW}$ (Baloch et al., 2016), against its potential of approximately $320 \mathrm{GW}$, as documented by Mirza et al. (2015). According to Beck and Martinot (2004), Brown (2001) and Wüstenhagen et al. (2007), latent barriers to wind-power development include present policies, institutional hurdles, regulatory barriers, insufficient financial and fiscal incentives and often poor industrial and technological infrastructure.

Given the situation described, the purpose and focus of this paper is towards diagnosing the present electricity crisis in
Pakistan and to discuss the outlook for the diffusion of wind power in the mix of the larger established electricitygeneration technologies. Specific recommendations are presented towards overcoming identified challenges and obstacles to the harnessing of the country's RE resources, especially its wind power potential.

\section{Electricity generation, supply and demand in Pakistan}

\subsection{Electric power sector entities}

Power generation in Pakistan comprises of a mix of thermal, hydroelectric, nuclear and RE units. At present, a number of entities working under the umbrella of the Government of Pakistan (GoP) (as illustrated in Figure 2) are responsible for the planning, generation and T\&D of electricity to the end users. Essentially, there are two vertically integrated bodies: (i) the Pakistan Electric Power Company (PEPCO), created in 2007 as bifurcation of the Water and Power Development 


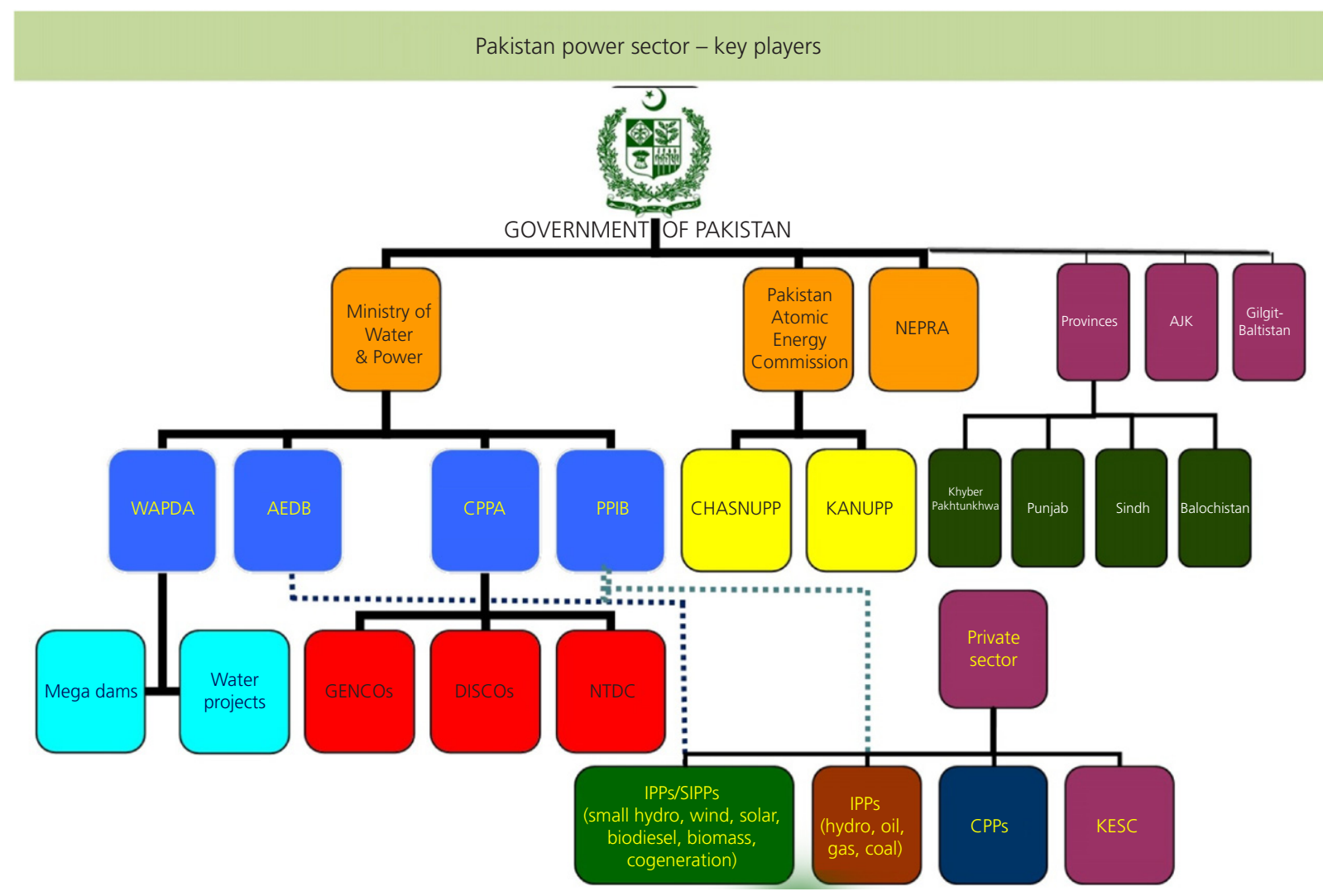

Figure 2. Organogram for power sector entities in Pakistan (adapted from Kessides, 2013; Perwez et al., 2015; Qazi et al., 2017)

Authority (WAPDA) and authorised to operate throughout Pakistan apart from Karachi city and surrounding areas; (ii) the Karachi Electric Supply Corporation (KESC), which functions in the private sector. In April 2012, with the worsening power crisis, the PEPCO's Board of Directors approved its dissolution, with its functions transferring to the National Transmission and Dispatch Company (NTDC) and later to the Central Power Purchasing Agency (CPPA) (Kessides, 2013; Valasai et al., 2017). The functions of the National Electric Power Regulatory Authority (NEPRA) include the regulation of the electric power sector, encompassing the granting of licences, tariff determination and prescribing performance standards (Zakaria and Noureen, 2016).

Referring to Figure 2, WAPDA is responsible for giving a unified direction for the development of water projects and hydropower (Shaikh et al., 2015). Before its dissolution, PEPCO was fully empowered and remains responsible for the management of ten corporatised distribution companies (DISCOs), four public sector electricity generation companies (GENCOs) and the NTDC (Baloch et al., 2016). More than 30 independent power producers (IPPs) also significantly contribute to electricity generation in Pakistan and are regulated and systematised through CPPA and KESC. Further details on the roles and responsibilities of the different entities referred to above can be found in the work of Amjid et al. (2011), Mirza et al. (2008), Perwez et al. (2015), Shaikh et al. (2015) and Valasai et al. (2017).

\subsection{Electricity supply and demand situation in Pakistan}

As depicted in Figure 3, the total installed electricitygeneration capacity was marginally higher than the peak electricity demand over the period 2010-2015. However, with the actual maximum generation capacity limited to $18.5 \mathrm{GW}$ due to issues such as high petroleum prices, availability of indigenous energy sources, electricity T\&D losses, sub-optimal power plant efficiency and circular debt, the shortfall between supply and demand during peak periods frequently reached up to $8 \mathrm{GW}$ (Mengal et al., 2014; NEPRA, 2017).

It is projected that without the required corrective measures, the supply-demand shortfall may reach up to $13 \mathrm{GW}$ by the year 2020 (Kessides, 2013; Shaikh et al., 2015). As illustrated in Figure 4, over the period of 2010-2016, approximately 67\% of the installed electricity-generation capacity in Pakistan 


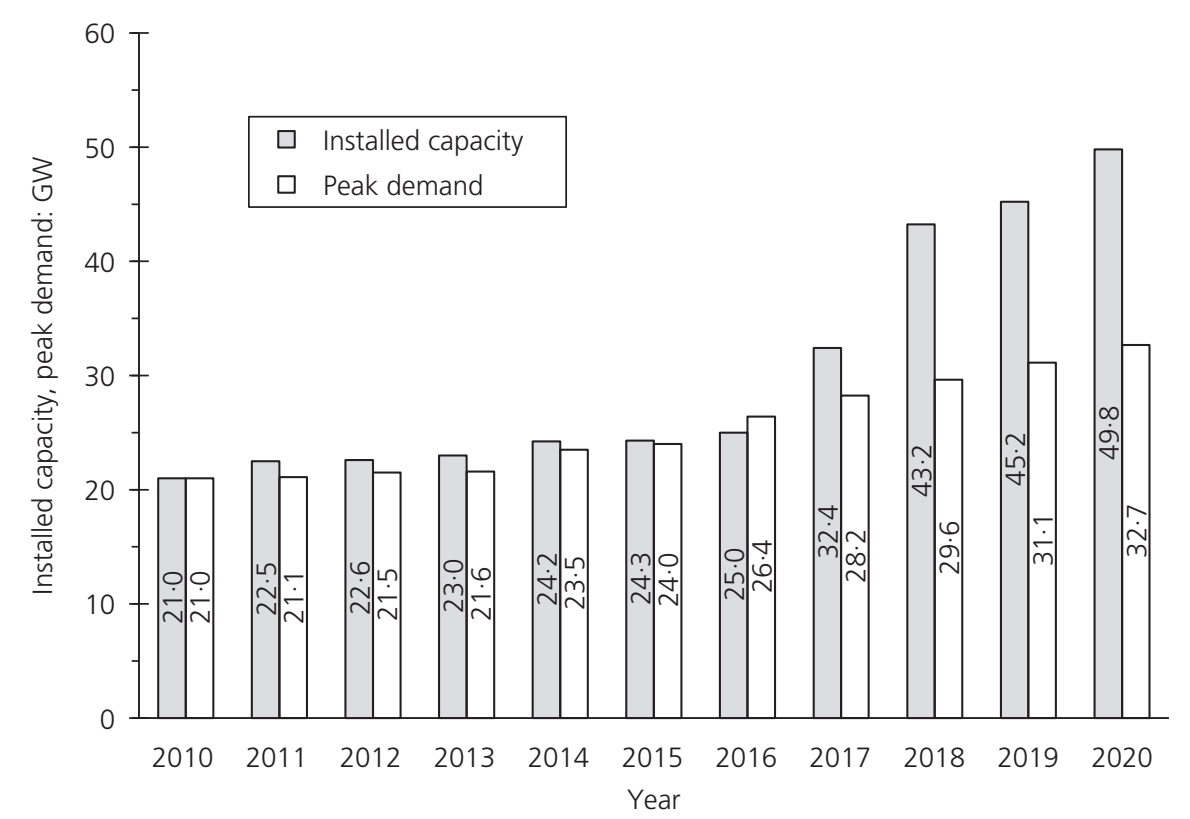

Figure 3. Recorded and projected installed capacity and peak demand of electricity in Pakistan (NEPRA, 2016; NTDC, 2017)

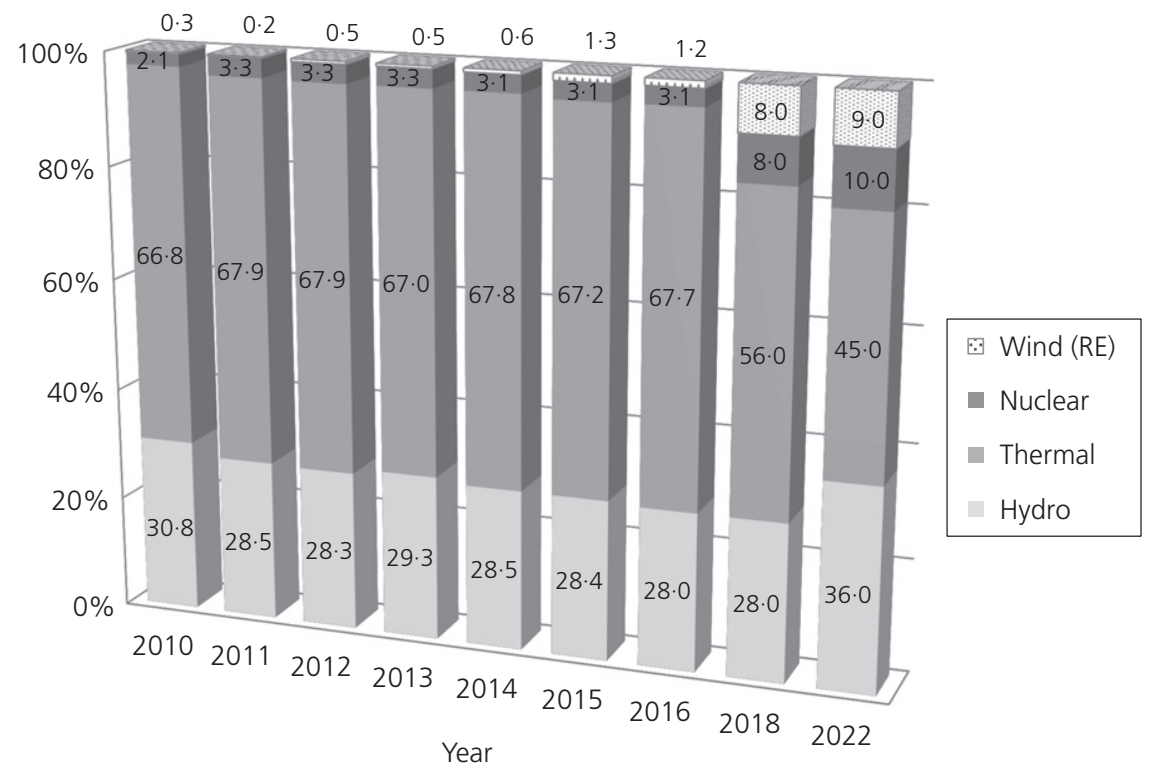

Figure 4. Electricity-generation sources in Pakistan. Note: 2010-2016 data are reported by NEPRA (2017) and NTDC (2017); 2018 and 2022 data are projections made by GIZ (2016)

was dependent on fossil fuels (liquefied natural gas, liquefied petroleum gas, furnace oil, natural gas), with approximately $29 \%$ from hydropower, $0 \cdot 2-1 \cdot 2 \%$ from wind power and approximately 3\% from nuclear power plants (Ahmed et al., 2016; NTDC, 2017; Perwez et al., 2015).
Most IPPs within Pakistan depend on imported fossil fuels at the cost of massive foreign exchange, thereby creating adverse pressures on the poor economy of the country (Farooqui, 2014; Harijan et al., 2011; SNC-Lavalin Inc., 2011). For instance, in the fiscal year 2016/2017, the oil import bill was almost 50\% 
(US\$20 billion) of total imports, practically equating to the country's total exports revenue. Although Pakistan has huge coal reserves, estimated at 185 billion tonnes, they have not been utilised to their full potential on account of their often poor quality, non-existence of necessary infrastructure, location drawbacks, transportation problems (Uqaili et al., 2003), lack of experience in advanced coal-combustion emissions control technologies and financial constraints. The scenario of nuclear power plants is promising in Pakistan, although high cost, technology barriers and international restrictions are the big hurdles. According to Harijan et al. (2011) and Uqaili et al. (2003, 2007), another reason is that Western countries are reluctant to collaborate with Pakistan regarding the expansion of nuclear power in the country.

Due to Pakistan's fast-growing economy and population, the expected swift industrialisation, electrification of villages, and increase in living standards, it is projected that electricity demand in the coming years will increase at the rate of $8-10 \%$ per annum (Javaid et al. (2011), cited by Shakeel et al. (2016)). As such, the country would require an installed electricitygeneration capacity of $54 \mathrm{GW}$ by 2020 and $113 \mathrm{GW}$ by 2030 in order fully to meet its electricity requirements (Javaid et al., 2011). The GoP power-generation plan up to 2030 predicts that electricity supply in Pakistan will increase at an average rate of $11 \%$ per annum, with $65 \%$ of the increase in installed capacity coming from thermal-based electricity generation (GoP, 2010). In other words, the current overdependence on fossil fuels for electricity generation is anticipated to continue. A study in the field of international co-operation for sustainable development by the Deutsche Gesellschaft für Internationale Zusammenarbeit GmbH (GIZ) (see GIZ, 2016), however, forecasts a distinctly different scenario, projecting that by 2022, the electricity-generation contribution from thermal power plants in Pakistan could reduce to $45 \%$ of the total installed electricitygeneration capacity, whereas the share from hydroelectric, nuclear and wind (or other RE resource) power plants could reach up to 36,10 and $9 \%$, respectively (see Figure 4).

\subsection{Sector-wise consumption of electricity in Pakistan}

Over the period of 2011-2016, the residential sector was the major consumer, accounting for almost $45 \%$ of all electricity produced in Pakistan, followed by the industrial (26.0\%), agricultural $(10 \cdot 26 \%)$ and commercial $(6 \cdot 64 \%)$ sectors (NEPRA, 2017; Trimble et al., 2011). Similar figure breakdowns have been reported by Mirza et al. (2015) and Perwez et al. (2015), and also for the period 2003-2004 by Perwez et al. (2015), with a similar trend expected to prevail up to 2030 .

With improvements in living standards, it is expected that given present growth trends, the demand for electricity from the residential sector will strongly increase in the near future. Further, the overall number of electricity consumers has increased on account of the increase in gross domestic product (GDP), the rapid rate of urbanisation (standing at $2 \cdot 77 \%$ per annum (CIA, 2017)) and the extension of the national grid to include additional rural areas; for instance, Kamran et al. (2015) reported a trend of approximately 7\% per annum increase in electricity consumers. In other words, based on this growth rate, the number of electricity consumers will substantially increase from 24 million in 2017 to 35 million and 50 million by the end of 2027 and 2037, respectively (Kamran et al., 2015), demonstrating the scope for future power-generation projects required in Pakistan. For the period 2005-2010, the average growth in electricity demand was $8 \%$ per annum, and is forcasted to continue at this rate to 2035 (NTDC, 2011), such that the total electricity demand could be up to $474 \mathrm{GW}$ by 2050 (Kamran et al., 2015).

\subsection{Electricity T\&D losses in Pakistan}

Figure 5 illustrates the involvement of the different power sector entities in Pakistan responsible for the generation and (or) purchase of electricity for delivery to the end users. Figure 6 shows schematically the electricity network encompassing generation, transmission and finally distribution to the end users.

By the end of 2016, the total length of electricity transmission lines in Pakistan was greater than $50000 \mathrm{~km}$ (NTDC, 2017).

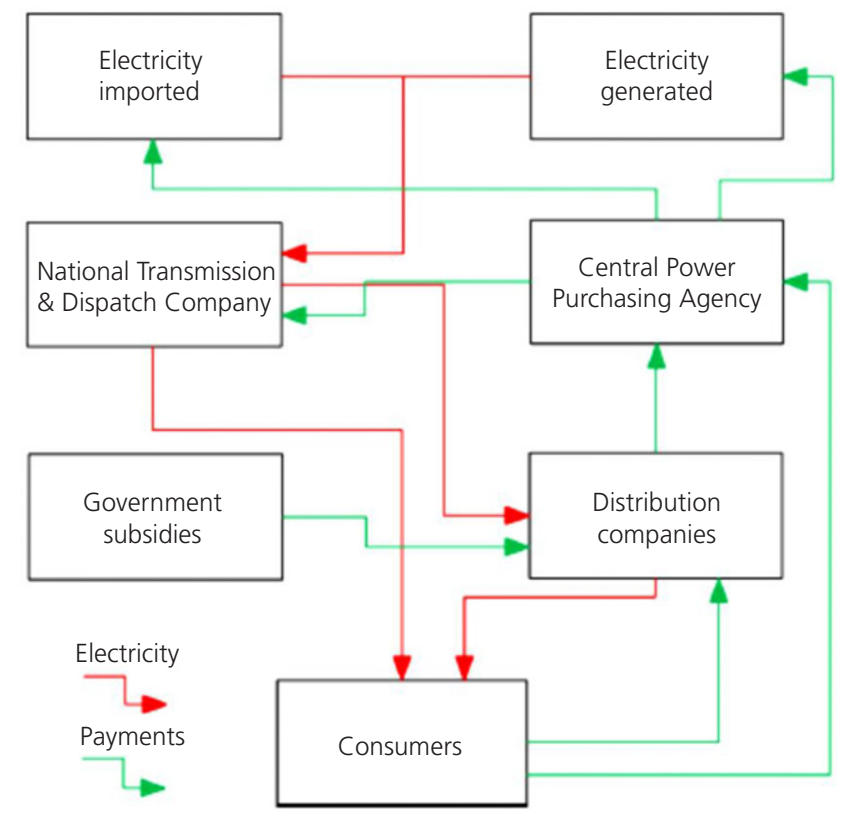

Figure 5. Involvement of different power sector entities responsible for electricity supply to the end users in Pakistan (Valasai et al., 2017) 


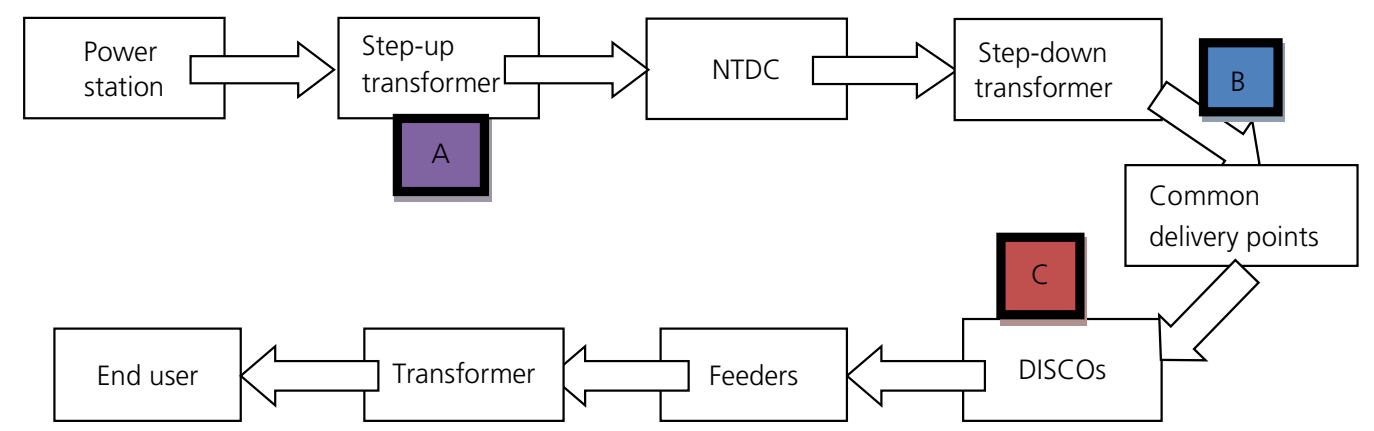

Figure 6. Electricity T\&D network in Pakistan

Referring to Figure 6: energy lost between points A and B is technically called transmission loss, whereas energy lost from point $\mathrm{B}$ onward is called distribution loss. While there are no sources in Pakistan for receiving meter readings at points B and $\mathrm{C}$ in real time, the country ranks as the 14 th highest among 131 countries considered for the level of electricity T\&D losses (Bhatti et al., 2015), with the NEPRA allowing for transmission and distribution losses of $3 \%$ and $10 \%$, respectively. However, the combined T\&D losses (expressed as percentages of the actual electricity generation at the power plants) for the NTDC and KESC networks in Pakistan are actually substantially greater, standing at approximately $20 \%$ and $32 \%$, respectively, for the period 2010-2016 (see Figure 7), These T\&D losses are very high when compared with other countries; for example they are significantly greater than the T\&D losses of $8 \%, 7 \%$ and $4 \%$ reported for China, the Organisation for Economic Cooperation and Development (OECD) and Korea, respectively (Malik (2012), cited by Shakeel et al. (2016)), and the worldwide average value of approximately $9 \%$ reported for the period 2011-2013 (USEIA, 2016). The primary causes cited for the electricity distribution losses in Pakistan are theft and the improper recording or reporting of electricity metering devices, with such non-technical losses estimated to account for over $33 \%$ of the total distribution system losses (Kessides, 2013). Electricity theft adversely impacts on the quality of electricity supply by increasing the load on the power-generation plants (Depuru et al., 2011) and also puts an added burden on paying customers through rising tariffs, although the price is often paid through government subsidies. The inevitable results of the presented picture are looming capacity shortfalls, load shedding and a raise in the public cost of electricity supply (Jamil, 2013).

Among other issues, the deprived electricity T\&D network in Pakistan is a key reason for the massive build-up of circular debt (financial imbalances among the power sector entities) and the increasing electricity supply-demand gap. Substantial government subsidies provided to untargeted end users also culminate in massive circular debt; for example, the GoP paid approximately US\$3 billion per annum in subsidies to end

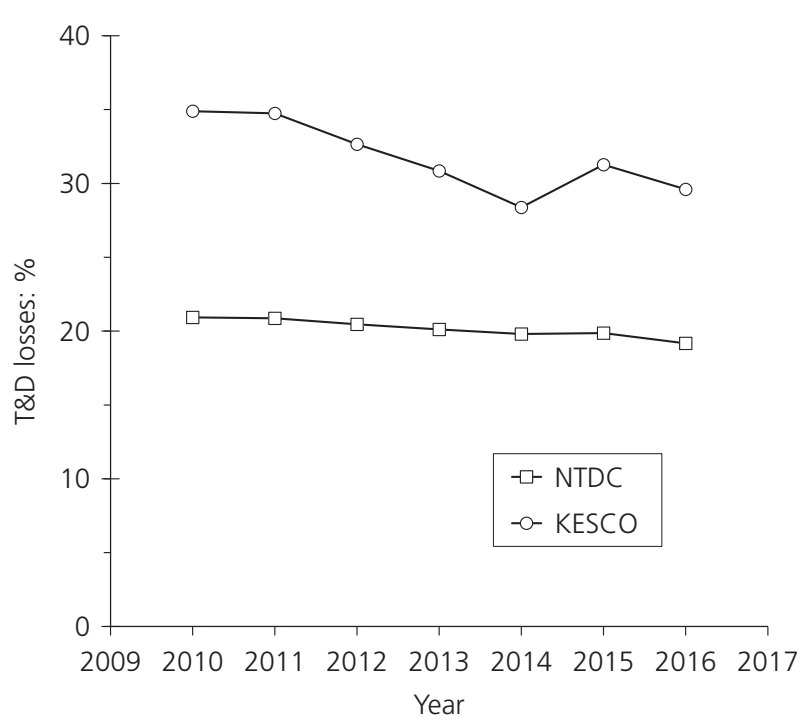

Figure 7. Electricity losses (based on net generation) during the T\&D process (NTDC, 2017)

users from 2010 to 2014 (Shakeel et al., 2016). Further details on the phenomenon of circular debt can be found in the papers by Khan and Abbas (2016) and Valasai et al. (2017).

According to Shaikh et al. (2015), even if the existing electricity power-generation plants were geared up to operate at three-quarters of their capacities, the country's present T\&D network simply does not have a capable and reliable infrastructure to distribute this power level to end users. In other words, the limitations of the present T\&D network are such that the country's actual generated electricity power remains substantially lower than the peak electricity demand (Mirza et al., 2008). As such, reducing the T\&D losses (and achieving other energy efficiencies) must rank among the highest priority energy strategies. In this regard, a number of government policy assessments and technical and administrative actions are 
recommended to reduce electricity losses, mainly requiring extra investments in improving the T\&D infrastructure and achieving greater operational and management efficiencies from generation to the end users (Bhatti et al., 2015).

\section{Wind power}

\subsection{Overview of the technology}

The increasing electricity demand with arguably inflated energy prices and real environmental concerns arising particularly from fossil-fuel-based energy sources has created a move worldwide to the utilisation of green energy sources. Globally, wind power plants represent the largest single source (at nearly 50\%) contributing to the increase in pollution-free electricity generation through RE resources, with almost $97 \%$ of all existing wind farms installed in the top and emerging markets; that is, the European Union, the United States, China and India (WWEA, 2015). Between 2011 and 2016, the share of wind power of global electricity demand increased from 2 to $4 \%$ and this may reach up to $20-41 \%$ by 2050 (GWEC, 2017; WWEA, 2015).

As discussed earlier, the wind-power industry is at an early stage in Pakistan, such that, to date, only onshore wind-power projects have been developed or are being considered in the country. Figure 8 illustrates the main components of an onshore windturbine system supported by a typical gravity-base foundation

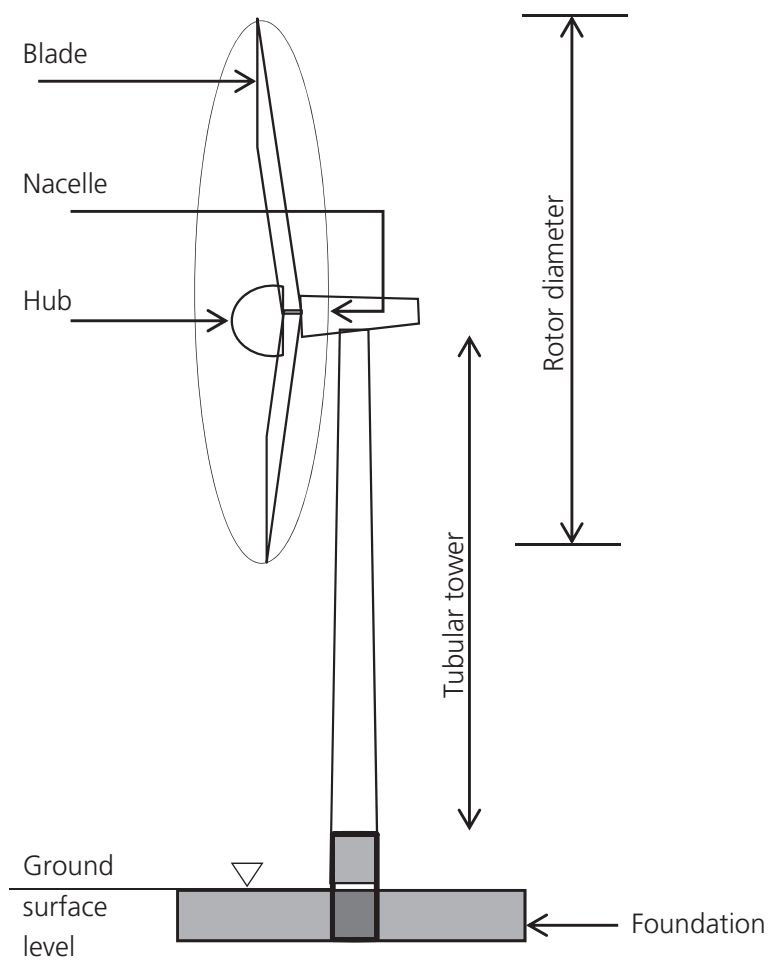

Figure 8. Main parts of an onshore wind-turbine system
(GBF). The turbines harness the wind's kinetic energy, providing the motive force to turn rotor blades and produce electricity by way of a rotor drive shaft, gears and a generator located in the nacelle unit. A critical determining factor for the wind power achievable at a particular site location is the rotor diameter, with longer blades covering more swept area, thereby capturing more energy from the passing wind (Şahin, 2004); however, this also mobilises a greater bending moment to be resisted by the foundation. Cast-in-situ reinforced concrete GBFs are invariably employed to resist the system of vertical, horizontal, moment and torsional loads arising from the self-weight and wind loading acting on the wind-turbine structure. The GBFs are normally octagonal in plan, or may be square or circular, with a characteristic width (diameter) of typically 15-20 m, and are usually founded at 2-3 $\mathrm{m}$ depth below ground level. Depending on the rated power-generation capacity of the wind turbine, the concrete volume required for one GBF may be up to $500 \mathrm{~m}^{3}$, with the excavated soil usually backfilled over the concrete slab foundation, thereby increasing its dead weight. A piled-raft foundation is typically used where the near-surface soil deposits provide insufficient allowable bearing pressure for GBFs. The foundations are designed to provide an adequate factor of safety against uplift, overturning, sliding and bearing-capacity failure modes and to limit (differential) settlement (i.e. tilting of the support tower) occurring over the project's design life within allowable limits. An important part of the design involves the analyses of the foundation response to the dynamic loading generated by wind turbulence blade-tower interaction as well as its seismic performance in earthquake-prone regions.

The levelised cost of energy (LCOE) is often cited as a convenient summary measure of the overall competitiveness of different energy-generating technologies. For wind power, LCOE represents the sum of all costs (i.e. including capital, operational and maintenance costs) over the project's lifetime, with financial flows discounted to a common year (Bhutto et al., 2013). The LCOE for onshore wind power varies by country, technology and project, although it typically ranges $0 \cdot 04-0 \cdot 16 \mathrm{US} \$ / \mathrm{kWh}$ globally (REN21, 2015) and is below $0.068 \mathrm{US} \$ \mathrm{kWh}$ for most projects located in higher source areas, including the United States, Brazil, Sweden and Mexico (REN21, 2015). The latter value compares favourably with estimated current average LCOEs of 0.067 and $0.056 \mathrm{US} \$ / \mathrm{kWh}$ for coal- and gas-fired power plants, respectively (Bhutto et al., 2013). In Pakistan, the NEPRA-recommended LCOE value of approximately $0 \cdot 10 \mathrm{US} \$ / \mathrm{kWh}$ was applied for most of the wind power projects presently under construction in the country, with this value reasonably on the lower side when compared with other RE resources, including solar, biogas and geothermal (Ali et al., 2015). Mengal et al. (2014) have empirically established that when compared with oil- and gas-fired power generation in the country, wind power is potentially the cheapest source of electricity generation for Pakistan. 
Table 1. Classification of wind power potential (Elliott, 2011)

\begin{tabular}{|c|c|c|c|}
\hline $\begin{array}{l}\text { Wind } \\
\text { power } \\
\text { class }\end{array}$ & $\begin{array}{l}\text { Resource } \\
\text { potential }\end{array}$ & $\begin{array}{c}\text { Wind power } \\
\text { density at } \\
50 \mathrm{~m} \text { AGL: } \mathrm{W} / \mathrm{m}^{2}\end{array}$ & $\begin{array}{l}\text { Wind speed } \\
\text { at } 50 \mathrm{~m} \\
\text { AGL: } \mathrm{m} / \mathrm{s}\end{array}$ \\
\hline 1 & Poor & $0-200$ & $0-5 \cdot 4$ \\
\hline 2 & Marginal & $200-300$ & $5 \cdot 4-6 \cdot 2$ \\
\hline 3 & Fair & $300-400$ & $6 \cdot 2-6 \cdot 9$ \\
\hline 4 & Good & $400-500$ & $6 \cdot 9-7 \cdot 4$ \\
\hline 5 & Excellent & $500-600$ & $7 \cdot 4-7 \cdot 8$ \\
\hline 6 & Outstanding & $600-800$ & $7 \cdot 8-8 \cdot 6$ \\
\hline 7 & Superb & $>800$ & $>8.6$ \\
\hline
\end{tabular}

$A G L$, above ground level

\subsection{Wind-power-generation potential in Pakistan}

The feasibility analysis for any wind power project involves many stages, with the first step invariably requiring the selection of a suitable site location for the project, wind speed being one key determining factor (Awan and Khan, 2014). For this purpose, the National Renewable Energy Laboratory (NREL) of the U.S. Department of Energy has categorised wind-power potential into seven classes according to the wind power density and speed at an elevation of $50 \mathrm{~m}$ above the ground level (AGL) for the particular site location under consideration (see Table 1).

For a complete assessment of the proposed site location and the viability of harvesting any RE resource, however, one often needs to consider different types of potentials (Awan and Khan, 2014; Farooq and Kumar, 2013); for instance, theoretical, geographical, technical, techno-economic and economic potentials (Farooq and Kumar, 2013; Hoogwijk, 2004; Raja et al., 1996), which are briefly explained as follows.

- Theoretical potential is the highest level of resource potential and only takes into account restrictions concerning natural and climatic parameters.

- Geographical potential is the theoretical potential limited by the resources at geographic locations that are suitable for the installation of specific technologies, such as wind farms.

- Technical potential is the geographical potential that can be attained using available technologies, while accounting for conversion efficiencies.

- Techno-economic potential is that achievable by applying technically feasible and economically viable technologies that are universally used in competitive markets.

- Economic potential is the technical potential at cost levels considered competitive.

To date, the wind power potential of Pakistan has neither been utilised significantly nor estimated confidently due to the lack of reliable and complete data for windy corridors
Table 2. Wind resource at $50 \mathrm{~m} \mathrm{AGL}$ for electricity generation in Pakistan (Elliott, 2011)

\begin{tabular}{lrrr}
$\begin{array}{l}\text { Wind } \\
\text { class }\end{array}$ & $\begin{array}{c}\text { Wind speed: } \\
\mathbf{m} / \mathbf{s}\end{array}$ & $\begin{array}{c}\text { Land area: } \\
\mathbf{k m}^{\mathbf{2}}\end{array}$ & $\begin{array}{c}\text { Electricity } \\
\text { potential: } \mathbf{G W}\end{array}$ \\
\hline 4 & $6 \cdot 9-7 \cdot 4$ & 18106 & 90 \\
5 & $7 \cdot 4-7 \cdot 8$ & 5218 & 26 \\
6 & $7 \cdot 8-8 \cdot 6$ & 2495 & 12 \\
7 & $>8 \cdot 6$ & 543 & 7 \\
& Total & 26362 & 135 \\
\hline
\end{tabular}

across the country (Mirza et al., 2007), with various agencies and researchers reporting widely different estimates for the country's exploitable wind power potential. Based on the wind map developed by the U.S. Department of Energy's NREL, and assuming 3\% of the total land area of Pakistan has good or excellent wind resources, there is approximately $346 \mathrm{GW}$ of wind power potential in Pakistan (Baloch et al., 2016; Elliott, 2011; Mengal et al., 2014), of which $120 \mathrm{GW}$ can be realistically harvested (Farooqui, 2014; Ghafoor et al., 2016). Based on satellite mapping performed by the U.S. Agency for International Development in collaboration with the NREL, Mirza et al. (2015) reported an estimated gross exploitable wind-power potential for the entire country of $132 \mathrm{GW}$, with the most promising wind corridor of Gharo-Keti Bandar, located in the southern coastal region, offering an estimated potential of $50 \mathrm{GW}$. Farooq and Kumar (2013) reported that for Pakistan, commercially exploitable wind-power potential is found only in southern Pakistan, with the gross wind-power potential in the coastal areas of the Sindh and Balochistan provinces estimated at $43 \mathrm{GW}$, based on a suitable area for wind power generation of $9700 \mathrm{~km}^{2}$, although according to Chaudhry and Afzaal (2004), various land utilisation constraints would limit this potential to $11 \mathrm{GW}$. Excluding low-wind areas and assuming a wind-power density of $5.4 \mathrm{~W} / \mathrm{m}^{2}$, Harijan et al. (2011) estimated the potential for electricity generation from wind along Pakistan's coastline as 123 GW. Ghayur (2006) and Mirza et al. (2010) indicated that $50 \mathrm{GW}$ of wind power potential exists along the country's coastal areas, with an average wind speed of typically more than $7 \mathrm{~m} / \mathrm{s}$ at $80 \mathrm{~m} \mathrm{AGL}$. For the Sindh province coastline, electricity-generation potentials from wind of $50 \mathrm{GW}$ (Boyd, 2009) and up to $20 \mathrm{GW}$ (Sheikh, 2010) were identified for reported monthly average wind speeds of approximately 8 and $5-12 \mathrm{~m} / \mathrm{s}$, respectively. Notwithstanding the differences in these reported exploitable wind power potential values, Pakistan's coastal areas, and especially the wind corridor in the Gharo region, appear ideal for generating electricity from wind energy.

A summary of the wind resource at $50 \mathrm{~m}$ AGL for Pakistan, along with the potential for electricity generation from the country's estimated exploitable wind resources, are presented in 
Table 2, with the following regions particularly identified as having good or excellent wind resources (Elliott, 2011).

- South-eastern Pakistan, especially the Hyderabad to Gharo region in the southern Indus valley, the coastal areas south of Karachi and the hills and ridges between Karachi and Hyderabad.

- Northern Indus valley, especially the hills and ridges in northern Punjab and the ridges and wind corridors near Mardan and Islamabad.

- South-western Pakistan, especially near Nokkundi and the hills and ridges in the Chagai and Makran areas.

- Elevated mountain summits and ridge crests, especially in northern Pakistan.

Vast areas of the Punjab and the northern areas of the country were reported as not suitable for exploiting wind energy for electricity generation (see PMD, 2018).

\subsection{Forecast diffusion of wind power in Pakistan}

The GoP has set targets for its Alternative Energy Development Board (AEDB) to install wind power plants having a combined capacity of $9.7 \mathrm{GW}$ by 2030 ; that is $5 \%$ of the total planned national power-generation capacity at that time (Harijan et al., 2011; Valasai et al., 2017). Wind power plants having a combined capacity of $900 \mathrm{MW}$ were operational at the time of writing this paper, with a further $700 \mathrm{MW}$ of installed capacity anticipated by mid-2019. Further, as documented by Harijan et al. (2011), the AEDB has issued more than 94 letters of intent to private sector wind-power investors for $50 \mathrm{MW}$ capacity sites; if fully realised, these projects would collectively represent an additional $4 \cdot 7 \mathrm{GW}$ generation capacity.

Harijan et al. (2011) forecasted that by 2030, approximately $50 \cdot 6$, $69 \cdot 6$ and $87 \cdot 7 \mathrm{GW}$ of wind power projects could be installed in Pakistan for standard, moderate and optimistic scenarios, respectively, representing approximately 42,58 and $73 \%$ of the reported total wind-power-generation technical potential of $120 \mathrm{GW}$ for the country (Farooqui, 2014; Ghafoor et al., 2016). Further, by 2030, wind power plants could generate 111, 152 and 192 TW-h of electricity for the identified standard, moderate and optimistic scenarios, respectively. Based on a capacity factor value of $25 \%$, AEDB estimated that the standard scenario investigated equates to 12.5 and $25 \mathrm{GW}$ of wind-power addition to the electricity grid by 2030 and 2036, respectively (Farooqui, 2014).

\subsection{Snags for the realisation of wind power generation in Pakistan}

As described earlier in the paper and as reported by Sahir and Qureshi (2008), wind is the most promising RE resource for electricity generation in Pakistan, although, to date, this resource has been significantly underutilised, with the main reasons cited for the limited private sector investment and slow progress in the development of wind power projects given as the following.

- Low credibility and capacity of pertinent regulatory and monitoring bodies (Perwez et al., 2015).

- Administrative delays and (or) technical uncertainties arising from, for instance: $(i)$ time-consuming administrative procedures associated with the issuance of different types of licences and approvals (Mirza et al., 2009; Rauf et al., 2015); (ii) lack of reliable countrywide wind speed data and general absence of wind data for remote locations suitable for wind farm installations (Ghafoor et al., 2016).

- Lack of infrastructure and logistic support; for example undependable grid connection capacity, poor manufacturing facilities and transport services (Shaikh et al., 2015), which demand additional capital investments, thereby undermining the cost-effectiveness and economic viability of the wind and other RE power projects.

- Relatively poor state and underinvestment in research and development $(\mathrm{R} \& \mathrm{D})$ facilities in the country (Ghafoor et al., 2016) and the knock-on effect of insufficient numbers of adequately trained indigenous personnel (Farooqui, 2014; Shaikh, et al., 2015).

- Insufficient release of funds for advancing RE projects, with the implementation of these projects likely to cause technological evolution in the industry (Rauf et al., 2015).

A couple of these points are elaborated further. Despite the establishment of the Pakistan Council for Renewable Energy Technology (PCRET) in 2001 (mandated with the development of RE projects in the country) and the AEDB in 2003, most degree-awarding institutes and universities in Pakistan unfortunately remain deficient in specialised laboratories and (or) equipment necessary for performing high-quality research work in the field of wind-power engineering, with a knock-on effect that sufficient numbers of adequately trained personnel are not being produced annually to meet the industry needs in Pakistan.

The lack or absence of reliable wind speed data for the country prevents realistic assessments of the wind-energy potentials for possible wind farm sites. To assemble the wind climatology necessary for a reasonable assessment of the wind-energy resource at an identified site, a minimum 1 year period of wind measurements is required (Al-Yahyai et al., 2010; AWS Scientific, 1997; Ganesan and Ahmed, 2008), with the associated degree of uncertainty typically ranging 5-15\% (Frandsen and Christensen, 1992). Realistic assessment of the windenergy potential requires statistical analysis of the wind data, including wind speed (preferably recorded at hub height), speed-frequency distribution, wind shear (i.e. rate of change in wind speed with elevation AGL), turbulence intensity 
(i.e. standard deviation of wind speeds sampled over $10 \mathrm{~min}$ period as a function of mean speed), wind direction distribution and also for extreme wind gusts having return periods of up to 50 and 100 years (Arshad and O'Kelly, 2013; DNV, 2014).

\section{Suggestions for promoting rapid development of wind power projects in Pakistan}

A multidisciplinary approach is required to make the windpower industry more cost-effective and for the faster development of wind power projects, including the following.

- Implementation of more effective policies and strengthening of regulatory frameworks should encourage more private sector investment and participation in renewable electricity production, as well as with associated retail and revenue collection (Kessides, 2013), with effective monitoring and evaluation systems involving third-party validation and endorsement criteria proposed at the governance level (Qazi et al., 2017).

- Development of transparent, fair and consistent investorfriendly national RE policies and legislations designed to shift the overreliance on electricity production from fossil fuels to RE resources, with due consideration for tax rebates, financial leasing and surety on safe investment through banks and (or) institutions (Shakeel et al., 2016). Current heavy government subsidies for fossil fuels should be dissuaded in order to encourage and improve the adaptability of wind power production as a profitable business and investment (Bhutto et al., 2013; Mirza et al., 2009).

- Transformation of the AEDB and PCRET entities by the GoP into state-of-the-art institutions, as well as the establishment and growth of R\&D centres of excellence in the field of REs, in order to ensure the development of planned and future RE projects.

- Science and engineering universities and institutes should embed issues pertaining to the development and implementation of RE technologies, especially for wind-power generation, in undergraduate and graduate curricula, combining analytical with experimental methods in a research-intensive environment, with the dual aims of developing and refining appropriate RE technologies for sustainable development and providing sufficient numbers of trained personnel for the industry.

- Strategic investment in the electricity T\&D network, grid connection infrastructure and logistic supports.

- Development of a comprehensive and reliable countrywide wind-speed database, commencing with particular locations identified as most suitable for wind farm installations.

\section{Summary and recommendations}

At present, the electricity-generation mix in Pakistan is highly skewed towards thermal electricity, with oil and natural gas leading the production. This situation is not sustainable for a number of reasons, including the increase in electricity-related carbon dioxide emissions and the likely rise in electricity prices that would make electricity unaffordable for the masses. The situation would be further aggravated in the absence of a modernised electricity T\&D network and metering system. On the production side, the situation clearly demands fuel diversification, incorporating significantly increased utilisation of indigenous alternative-energy resources toward solving the country's present electricity crisis and furnishing longer-term electricity needs. Wind power is identified as the most promising of the available RE resources in Pakistan.

The following recommendations are made towards mitigating the present electricity crisis and significantly increasing the contribution of wind power to the country's total energy mix.

- Reductions in non-technical losses and enhancing investment attractiveness (for both thermal and renewable) are likely to facilitate improved and affordable electricity supply.

- Implementation of more effective, transparent and consistent policies, along with the strengthening of regulatory frameworks, for supporting greater renewable electricity production, combined with independent monitoring and evaluation at the governance level.

- Although there are some guidelines for the operation of IPPs, the private sector should be given appropriate roles in the T\&D and retail of electricity to the end users.

- Fuel diversification achieved by means of new RE production plants, with those plants that can be developed within a relatively shorter time period being given preference. For instance, based on the actual situation observed in Pakistan over the past 10 years, medium-sized wind farms can be typically developed within a 1-2 year period, compared with the typically 5-7 year period required for hydropower plants having similar electricitygeneration capacity.

- Upgrading and overhaul of the existing stock of thermal power plants and the electricity T\&D infrastructure along with the application of smart electricity metering systems.

- Targeted government funding of the country's energy R\&D sector for innovation, training, development of appropriate $\mathrm{RE}$ technologies and promotion of energy-saving technologies.

- A comprehensive study programme is required for the generation of a reliable countrywide database of windspeed characteristics and statistics, commencing with 
geographical regions identified as most promising for wind farm installations.

- Wide promotion campaign of an energy-efficiency policy, with due consideration for the implementation of the manufacturing standards on electrical appliances, so that substandard and inefficient devices may be withdrawn from the market.

From the authors' perspectives, the ensuing benefits from such reforms will not be fully realised without keen interest at the governance level of the country.

\section{REFERENCES}

Abbas T, Bazmi AA, Bhutto AW and Zahedi G (2014) Greener energy: issues and challenges for Pakistan-geothermal energy prospective. Renewable and Sustainable Energy Reviews 31: 258-269.

Ahmed S, Mahmood A, Hasan A, Sidhu GAS and Butt MFU (2016) A comparative review of China, India and Pakistan renewable energy sectors and sharing opportunities. Renewable and Sustainable Energy Reviews 57: 216-225.

Al-Yahyai S, Charabi Y and Gastli A (2010) Review of the use of numerical weather prediction (NWP) models for wind energy assessment. Renewable and Sustainable Energy Reviews 14(9) 3192-3198.

Ali SMH, Zuberi MJS, Tariq MA, Baker D and Mohiuddin A (2015) A study to incorporate renewable energy technologies into the power portfolio of Karachi, Pakistan. Renewable and Sustainable Energy Reviews 47: 14-22.

Amjid SS, Bilal MQ, Nazir MS and Hussain A (2011) Biogas, renewable energy resource for Pakistan. Renewable and Sustainable Energy Reviews 15(6): 2833-2837.

Arshad M and O'Kelly BC (2013) Offshore wind-turbine structures: a review. Proceedings of the Institution of Civil Engineers - Energy 166(4): 139-152, https://doi.org/10.1680/ener.12.00019.

Awan AB and Khan ZA (2014) Recent progress in renewable energy remedy of energy crisis in Pakistan. Renewable and Sustainable Energy Reviews 33: 236-253.

AWS Scientific (1997) Wind Resource Assessment HandbookFundamentals for Conducting a Successful Monitoring Program. AWS Scientific, Inc., Albany, NY, USA, NREL Subcontract No. TAT-5-15283-01. See http://www.nrel.gov/docs/legosti/fy97/22223. pdf (accessed 12/01/2018).

Baloch MH, Kaloi GS and Memon ZA (2016) Current scenario of the wind energy in Pakistan challenges and future perspectives: a case study. Energy Reports 2: 201-210.

Beck F and Martinot E (2004) Renewable energy policies and barriers. In Encyclopedia of Energy (Cleveland CJ (ed.)). Elsevier, San Diego, CA, USA, vol. 5, pp. 365-383.

Bhatti SS, Lodhi MUU, Haq SU et al. (2015) Electric power transmission and distribution losses overview and minimization in Pakistan. International Journal of Scientific \& Engineering Research 6(4): 1108-1112.

Bhutto AW, Bazmi AA and Zahedi G (2011) Greener energy: issues and challenges for Pakistan - biomass energy prospective. Renewable and Sustainable Energy Reviews 15(6): 3207-3219.

Bhutto AW, Bazmi AA and Zahedi G (2012) Greener energy: issues and challenges for Pakistan - hydel power prospective. Renewable and Sustainable Energy Reviews 16(5): 2732-2746.
Bhutto AW, Bazmi AA and Zahedi G (2013) Greener energy: issues and challenges for Pakistan - wind power prospective. Renewable and Sustainable Energy Reviews 20: 519-538.

Boyd E (2009) Governing the clean development mechanism: global rhetoric versus local realities in carbon sequestration projects. Environment and Planning A: Economy and Space 41(10): 2380-2395.

Brown MA (2001) Market failures and barriers as a basis for clean energy policies. Energy Policy 29(14): 1197-1207.

Chaudhry QUZ and Afzaal HMM (2004) The Establishment of Commercial Wind Power Plant of 18MW at Gharo - Sindh. Pakistan Meteorological Department, Islamabad, Pakistan, Technical Report no. PMD-11/2004. See http://www.pmd.gov.pk/wind/Wind_Project_ files/Feasibility\%20Report-Gharo.pdf (accessed 12/01/2018).

CIA (Central Intelligence Agency) (2017) Pakistan - The World Factbook 2017. Central Intelligence Agency, Washington, DC, USA. See https://www.cia.gov/library/publications/the-worldfactbook/geos/pk.html (accessed 06/07/2017).

Depuru SSSR, Wang L and Devabhaktuni V (2011) Electricity theft: overview, issues, prevention and a smart meter based approach to control theft. Energy Policy 39(2): 1007-1015.

DNV (Det Norske Veritas) (2014) DNV-OS-J101: Design of offshore wind turbine structures. Det Norske Veritas, Oslo, Norway.

Elliott D (2011) Wind Resource Assessment and Mapping for Afghanistan and Pakistan. National Renewable Energy Laboratory, U.S. Department of Energy, Golden, CO, USA. See http://www. nrel.gov/international/pdfs/afg_pak_wind_june07.pdf (accessed 12/01/2018)

Farooq MK and Kumar S (2013) An assessment of renewable energy potential for electricity generation in Pakistan. Renewable and Sustainable Energy Reviews 20: 240-254.

Farooqui SZ (2014) Prospects of renewables penetration in the energy mix of Pakistan. Renewable and Sustainable Energy Reviews 29 693-700.

Frandsen S and Christensen CJ (1992) Accuracy of estimation of energy production from wind power plants. Wind Engineering 16(5): $257-268$.

Ganesan S and Ahmed S (2008) Assessment of wind energy potential using topographical and meteorological data of a site in Central India (Bhopal). International Journal of Sustainable Energy 27(3): 131-142.

Ghafoor A, Ur Rehman T, Munir A, Ahmad M and Iqbal M (2016) Current status and overview of renewable energy potential in Pakistan for continuous energy sustainability. Renewable and Sustainable Energy Reviews 60: 1332-1342.

Ghayur A (2006) Role of satellites for renewable energy generation technologies in urban regional and urban settings. In Proceedings of the 2006 International Conference on Advances in Space Technologies. Institute of Electrical and Electronics Engineers, Piscataway, NJ, USA, pp. 157-161.

GIZ (Deutsche Gesellschaft für Internationale Zusammenarbeit GmbH) (2016) Pakistan Energy Sector and Prospects for Business. See https://hamburg.hk24.de/Veranstaltung/Anlagen/VSDB/131017785/ Pakistan_Business_Day_Khan.pdf (accessed 08/02/2018).

GoP (Government of Pakistan) (2010) Pakistan Economic Survey 2009-10. Economic Advisor's Wing, Ministry of Finance, Government of Pakistan, Islamabad, Pakistan. See http://www. finance.gov.pk/survey_0910.html (accessed 12/01/2018).

GWEC (Global Wind Energy Council) (2017) Global Wind Energy Outlook 2016: Wind Power to Dominate Power Sector Growth. Global Wind Energy Council, Brussels, Belgium. See http://www. gwec.net/publications/global-wind-energy-outlook/global-windenergy-outlook-2016/ (accessed 10/07/2017). 
Harijan K, Uqaili MA, Memon M and Mirza UK (2011) Forecasting the diffusion of wind power in Pakistan. Energy 36(10): 6068-6073, https://doi.org/10.1016/j.energy.2011.08.009.

Hoogwijk MM (2004) On the Global and Regional Potential of Renewable Energy Sources. PhD thesis, Utrecht University, Utrecht, the Netherlands.

Jabeen M, Umar M, Zahid M et al. (2014) Socio-economic prospects of solar technology utilization in Abbottabad, Pakistan. Renewable and Sustainable Energy Reviews 39 1164-1172.

Jamil F (2013) On the electricity shortage, price and electricity theft nexus. Energy Policy 54: 267-272.

Javaid MA, Hussain S, Maqsood A et al. (2011) Electrical energy crisis in Pakistan and their possible solutions. International Journal of Basic \& Applied Sciences 11(5): 26-35.

Kamran A, Ali SN and Raufi F (2015) Wind power energy Pakistan economical renewable power resource. In Proceedings of the 9th International Conference on Management Science and Engineering Management (Xu J, Nickel S, Machado V and Hajiyev A (eds)). Springer, Berlin, Germany, pp. 575-589.

Kessides IN (2013) Chaos in power: Pakistan's electricity crisis Energy Policy 55: 271-285.

Khalil HB and Zaidi H (2014) Energy crisis and potential of solar energy in Pakistan. Renewable and Sustainable Energy Reviews 31: 194-201.

Khan MA and Abbas F (2016) The dynamics of electricity demand in Pakistan: a panel cointegration analysis. Renewable and Sustainable Energy Reviews 65: 1159-1178.

Latif A and Ramzan N (2014) A review of renewable energy resources in Pakistan. Journal of Global Innovations in Agricultural and Social Sciences 2(3): 127-132.

Malik A (2012) Power Crisis in Pakistan: A Crisis in Governance?. Pakistan Institute of Development Economics, Islamabad, Pakistan. See http://pide.org.pk/pdf/publications/Monograph/ Monograph-4-Afia\%20Malik.pdf (accessed 12/01/2018).

Mengal A, Uqaili MA, Harijan K and Memon AG (2014) Competitiveness of wind power with the conventional thermal power plants using oil and natural gas as fuel in Pakistan. Energy Procedia 52: 59-67.

Mirza UK, Ahmad N, Majeed T and Harijan K (2007) Wind energy development in Pakistan. Renewable and Sustainable Energy Reviews 11(9): 2179-2190.

Mirza UK, Ahmad N and Majeed T (2008) An overview of biomass energy utilization in Pakistan. Renewable and Sustainable Energy Reviews 12(7): 1988-1996.

Mirza UK, Ahmad N, Harijan K and Majeed T (2009) Identifying and addressing barriers to renewable energy development in Pakistan. Renewable and Sustainable Energy Reviews 13(4): 927-931.

Mirza IA, Khan NA and Memon N (2010) Development of benchmark wind speed for Gharo and Jhimpir, Pakistan. Renewable Energy 35(3): 576-582.

Mirza IA, Khalil MS, Amer M and Daim TU (2015) Assessment of wind potential in Kalar Kahar region by comparing on-site data with NREL wind resource map of Pakistan. In Policies and Programs for Sustainable Energy Innovations (Innovation, Technology, and Knowledge Management) (Daim T, Kim J, Iskin I, Abu Taha R and van Blommestein K (eds)). Springer International Publishing, Cham, Switzerland, pp. 55-81

NEPRA (National Electric Power Regulatory Authority) (2016) State of Industry Report 2015. National Electric Power Regulatory Authority, Islamabad, Pakistan. See http://www.nepra.org. pk/Publications/State $\% 20$ of $\% 20$ Industry $\% 20$ Reports $/$ State $\% 20$ of $\%$ 20Industry\%20Report\%202015.pdf (accessed 12/01/2018).
NEPRA (2017) State of Industry Report 2016. National Electric Power Regulatory Authority, Islamabad, Pakistan. See http://www.nepra org.pk/Publications/State $\% 20$ of $\% 20$ Industry $\% 20$ Reports/NEPRA $\% 20$ State $\% 20$ of $\% 20$ Industry $\% 20$ Report $\% 202016$.pdf (accessed $12 / 01 / 2018)$.

NTDC (National Transmission and Despatch Company) (2011) Electricity Demand Forecast Based on Multiple Regression Analysis (Period 2011 to 2035). National Transmission and Despatch Company, Lahore, Pakistan. See http://www.ntdc.com.pk/EDF20112035.pdf (accessed 12/01/2018).

NTDC (2017) Power System Statistics 2015-2016, 41st edn. National Transmission and Despatch Company, Lahore, Pakistan. See http://www.ntdc.com.pk/Files/Power $\% 20$ System $\% 20$ Statistics $\%$ 2041st\%20Edition.pdf (accessed 12/01/2018).

PMD (Pakistan Meteorological Department) (2018) Wind Power Potential of Pakistan. See http://www.pmd.gov.pk/wind/Wind_Project_files/ Page694.html (accessed 08/02/2018).

Perwez U, Sohail A, Hassan SF and Zia U (2015) The long-term forecast of Pakistan's electricity supply and demand: an application of long range energy alternatives planning. Energy 93(2): 2423-2435, https://doi.org/10.1016/j.energy.2015.10.103.

Qazi U, Jahanzaib M, Ahmad W and Hussain S (2017) An institutional framework for the development of sustainable and competitive power market in Pakistan. Renewable and Sustainable Energy Reviews 70: 83-95.

Raja IA, Dougar MG and Abro RS (1996) Solar energy applications in Pakistan. Renewable Energy 9(1-4): 1128-1131.

Rauf O, Wang S, Yuan P and Tan J (2015) An overview of energy status and development in Pakistan. Renewable and Sustainable Energy Reviews 48: 892-931.

REN21 (Renewables Energy Policy Network for the 21st Century) (2015) Renewables 2015 Global Status Report. Renewables Energy Policy Network for the $21^{\text {st }}$ Century Secretariat, Paris, France. See http://www.ren21.net/wp-content/uploads/ 2015/07/REN12-GSR2015_Onlinebook_low1.pdf (accessed $12 / 01 / 2018)$.

Şahin AD (2004) Progress and recent trends in wind energy. Progress in Energy and Combustion Science 30(5): 501-543.

Sahir MH and Qureshi AH (2008) Assessment of new and renewable energy resources potential and identification of barriers to their significant utilization in Pakistan. Renewable and Sustainable Energy Reviews 12(1): 290-298.

Shaikh F, Ji Q and Fan Y (2015) The diagnosis of an electricity crisis and alternative energy development in Pakistan. Renewable and Sustainable Energy Reviews 52: 1172-1185.

Shakeel SR, Takala J and Shakeel W (2016) Renewable energy sources in power generation in Pakistan. Renewable and Sustainable Energy Reviews 64: 421-434.

Sheikh MA (2010) Energy and renewable energy scenario of Pakistan. Renewable and Sustainable Energy Reviews 14(1) 354-363.

SNC-Lavalin Inc. (2011) National Power System Expansion Plan 2011-2030. SNC-Lavalin Inc., Montreal, Québec, Canada, Final Report 504760-01-MR. See http://climateinfo. $\mathrm{pk} /$ frontend/web/attachments/data-type/PSEP $\% 2001 \% 20 \mathrm{Main} \%$ 20Report.pdf (accessed 12/01/2018).

Trimble C, Yoshida N and Saqib M (2011) Rethinking Electricity Tariffs and Subsidies in Pakistan. World Bank, Washington, DC, USA. See http://hdl.handle.net/10986/19456 (accessed 12/01/2018).

Ullah K (2013) Electricity infrastructure in Pakistan: an overview. International Journal of Energy, Information and Communications 4(3): 11-26. 
Uqaili MA, Harijan K and Mirani M (2003) Demand projections and supply options for power generation in Pakistan. Mehran University Research Journal of Engineering and Technology 22(4): 233-242.

Uqaili MA, Harijan K and Memon M (2007) Prospects of renewable energy for meeting growing electricity demand in Pakistan. In Renewable Energy for Sustainable Development in the Asia Pacific Region (AIP Conference Proceedings) (Jennings P, Ho G, Mathew K and Nayer CV (eds)). AIP Publishing, Melville, NY, USA. vol. 941, pp. 53-61.

USEIA (US Energy Information Administration) (2016) Annual Energy Outlook 2016. US Energy Information Administration, Washington, DC, USA. See http://www.eia.gov/outlooks/ aeo/pdf/0383(2016).pdf (accessed 12/01/2018).

Valasai GD, Uqaili MA, Memon HR et al. (2017) Overcoming electricity crisis in Pakistan: a review of sustainable electricity options. Renewable and Sustainable Energy Reviews 72: 734-745.

Wüstenhagen R, Wolsink M and Bürer MJ (2007) Social acceptance of renewable energy innovation: an introduction to the concept. Energy Policy 35(5): 2683-2691.

WWEA (World Wind Energy Association) (2015) Wind Energy 2050 On the Shape of Near 100\% RE Grid. World Wind Energy Association, Bonn, Germany, WWEA Technical Committee Report on Grid Integration. See http://www.wwindea.org/ download/technology/GRID_INTEGRATION_Wind_Energy_ 2050.pdf (accessed 12/01/2018).

Zakaria M and Noureen R (2016) Benchmarking and regulation of power distribution companies in Pakistan. Renewable and Sustainable Energy Reviews $\mathbf{5 8}$ 1095-1099.

\section{How can you contribute?}

To discuss this paper, please email up to 500 words to the editor at journals@ice.org.uk. Your contribution will be forwarded to the author(s) for a reply and, if considered appropriate by the editorial board, it will be published as discussion in a future issue of the journal.

Proceedings journals rely entirely on contributions from the civil engineering profession (and allied disciplines). Information about how to submit your paper online is available at www.icevirtuallibrary.com/page/authors, where you will also find detailed author guidelines. 